\title{
Screening of plants found in the State of Amazonas, Brazil for larvicidal activity against Aedes aegypti larvae.
}

\author{
Adrian Martin POHLIT, ${ }^{\mathrm{a}, 1}$ Etienne Louis Jacques QUIGNARD, ${ }^{\mathrm{a}}$ Sergio Massayoshi NUNOMURA, ${ }^{\mathrm{a}}$ Wanderli \\ Pedro TADEI, ${ }^{\mathrm{b}}$ Ari de Freitas HIDALGO, ${ }^{\mathrm{c}}$ Ana Cristina da Silva PINTO, ${ }^{\mathrm{d}}$ Elba Vieira Mustafa dos SANTOS, ${ }^{\mathrm{d}}$ \\ Sabrina Kelly Reis de MORAIS, ${ }^{\mathrm{d}}$ Rita De Cássia Guedes SARAIVA, ${ }^{\mathrm{e}}$ Lin Chau MING, ${ }^{\mathrm{f}}$ Alexandre Mascarenhas \\ ALECRIM, ${ }^{a}$ Alfeu de Barros FERRAZ, ${ }^{a}$ Andreza Cristiana da Silva PEDROSO, ${ }^{a}$ Elisangela Vieira DINIZ, ${ }^{a}$ Ellen \\ Kathryn FINNEY, ${ }^{a}$ Erika de Oliveira GOMES, ${ }^{a}$ Hercules Bezerra DIAS, ${ }^{a}$ Katiuscia dos Santos de SOUZA, ${ }^{a}$ Laura \\ Cristina Pereira de OLIVEIRA, ${ }^{a}$ Luciana de Castro DON, ${ }^{a}$ Maria Mireide Andrade QUEIROZ, ${ }^{a}$ Marycleuma \\ Campos HENRIQUE, ${ }^{a}$ Mirian dos SANTOS, ${ }^{a}$ Orivaldo da Silva LACERDA JÚNIOR, ${ }^{a}$ Patrícia de Souza PINTO, ${ }^{a}$ \\ Suniá Gomes SILVA. ${ }^{a}$ Yara Rodrigues GRAÇA. ${ }^{a}$
}

\begin{abstract}
Ethanol, methanol and water extracts representing mostly native plant species found in the Amazon region were prepared, respectively, by maceration, continuous liquid-solid extraction and infusion, followed by evaporation and freeze-drying. The freeze-dried extracts were tested for lethality toward Aedes aegypti larvae at test concentrations of $500 \mu \mathrm{g} / \mathrm{mL}$. In general, methanol extracts exhibited the greatest larvicidal activity. The following 7 methanol extracts of (the parts of) the indicated plant species were the most active, resulting in $100 \%$ mortality in A. aegypti larvae: Tapura amazonica Poepp. (root), Piper aduncum L. (leaf and root), P. tuberculatum Jacq. (leaf, fruit and branch). and Simaba polyphylla (Cavalcante) W.W. Thomas (branch).
\end{abstract}

KEY WORDS

larvicide, Aedes aegypti, Tapura, Piper, Simaba, Amazonia.

\section{Triagem de plantas encontradas no Estado do Amazonas para atividade larvicida contra Aedes aegypti.}

\section{RESUMO}

Extratos aquosos, etanólicos e metanólicos, representando principalmente espécies vegetais nativas encontradas na região Amazônica, foram preparados, respectivamente, por infusão, maceração e extração contínua líquido-sólido, seguida de evaporação e liofilização. Os extratos liofilizados foram testados para atividade contra larvas de Aedes aegypti, na concentração única de $500 \mu \mathrm{g} / \mathrm{mL}$. Os extratos metanólicos foram, em geral, os que apresentaram maior atividade larvicida. Os seguintes 7 extratos metanólicos das (partes das) espécies vegetais indicadas foram os mais ativos, provocando $100 \%$ de mortalidade em larvas de A. aegypti: Tapura amazonica Poepp. (raiz), Piper aduncum $L$. (folha e raiz), P. tuberculatum Jacq. (folha, fruto e galbo) e Simaba polyphylla (Cavalcante) W.W. Thomas (galbo).

PALAVRAS-CHAVE

larvicida, Aedes aegypti, Tapura, Piper, Simaba, Amazônia.

\footnotetext{
${ }^{1}$ Author to whom correspondence should be addressed (e-mail: ampohlit@inpa.gov.br).

${ }^{a}$ Coordenação de Pesquisas em Produtos Naturais (CPPN), ${ }^{\text {b } C o o r d e n a c ̧ a ̃ o ~ d e ~ P e s q u i s a s ~ e m ~ C i e ̂ n c i a s ~ d a ~ S a u ́ d e ~(C P C S), ~ I n s t i t u t o ~ N a c i o n a l ~ d e ~ P e s q u i s a s ~}$ da Amazônia (INPA), Av. André Araújo, 2936, 69083-000 Manaus, Amazonas; 'Faculdade de Ciências Agrárias (FCA), ${ }^{\mathrm{d} C u r s o}$ de Pós-graduação em Química de Produtos Naturais, Universidade Federal do Amazonas (UFAM), Av. Gal. Rodrigo O. J. Ramos, 3000, 69077-000 Manaus, Amazonas; ${ }^{\mathrm{e}} \mathrm{Curso}$ de Pós-graduação em Química, Universidade Federal do Rio de Janeiro (UFRJ), Rio de Janeiro, Rio de Janeiro; ${ }^{\mathrm{f}}$ Universidade do Estado de São Paulo (UNESP), Fazenda Experimental Lageado, 237, 18603-970 Botucatu, São Paulo.
} 


\section{ACTA \\ AMAZONICA}

SCREENING OF PLANTS FOUND IN THE STATE OF AMAZONAS, BRAZIL

FOR LARVICIDAL ACTIVITY AGAINST Aedes aegypti LARVAE

\section{INTRODUCTION}

In response to strong selective pressures of herbivorous insects, toxic secondary metabolites have evolved in plants and often affect insect nerve function and behaviour (Sharma et al., 1998). Plant extracts show potential as sources of natural larvicides for the control of mosquito vectors and an early review has been published in which more than 300 larvicidal plant species were identified (Sukamar et al., 1991). In recent times, studies on the activity of plant extracts towards Aedes sp. larvae from different parts of the world, such as, North America (Bergeron et al., 1996), Argentina, Bolivia, Brasil and Peru (Chantraine et al., 1998; Ciccia et al., 2000; Macedo et al., 1997), Trinidade and Tobago (Chariandy et al., 1999), Mali (Diallo et al., 2001), Negev Desert (Sathiyamoorthy et al., 1997) and Africa (Marston et al., 1993), among others, have been published and have revealed numerous examples of active plant extracts representing diverse taxonomic groups. More systematic and directed studies have revealed a number of very active plant extracts, essential oils, and isolated larvicidal phytochemicals (Bandara et al., 2000; Bernard et al., 1995; Hostettmann \& Potterat, 1997; Latha \& Ammini, 2000; Lee, 2000; Oberlies et al., 1998; Park et al., 2002; Pushpalatha \& Muthukrishnan, 1999; Rahuman et al., 2000; Sharma et al., 1998; Thorsell et al., 1998). In the present study, we have screened polar extracts of mostly native plants from the Brazilian Amazon for activity against larvae of the hemorrhagic dengue fever vector, Aedes aegypti (Diptera: Culicidae), at a single test concentration of $500 \mu \mathrm{g} / \mathrm{mL}$. Data (species names, plant parts, extraction solvent) for both active and inactive extracts are presented.

\section{MATERIAL AND METHODS}

\section{Plant collecting, processing, and extract preparation.}

Plants were collected from 1999 to 2002 in the State of Amazonas. Some genera (for example, Piper and Aspidosperma) and families (Euphorbiaceae, Simaroubaceae, Apocynaceae, Piperaceae, etc.) were better represented among the plants collected due to our specific interest in the bioactivity of these taxonomic groups. The plant materials were generally dried on the ground, in the shade, then stored in plastic bags under the protective warmth and luminosity of incandescent lighting. Where possible, fertile specimens of plant species were collected, used for identification and deposited at the INPA Herbarium. Many samples for study were collected from individual trees in INPA's Ducke Reserve that had been catalogued and identified in recent systematic studies (Ribeiro et al., 1999). Ethanol, methanol and water extracts were prepared, respectively, by maceration, continuous liquid-solid extraction, and infusion, followed by rotary evaporation under vacuum with heating in a bath to ca. 40$45^{\circ} \mathrm{C}$ and freeze-drying. After this last step, extracts were presumed to be solvent-free. Dry extracts were deposited in our extract bank at the Coordenação de Pesquisas em Produtos Naturais (CPPN / INPA) where they were stored at $-19^{\circ} \mathrm{C}$. Many of these extracts were screened previously by some of us against larvae of the brine shrimp species Artemia franciscana (Quignard et al., 2003).

\section{Assay for larvicidal activity against Aedes aegypti.}

Aedes aegypti larvae were obtained by incubation of eggs from a laboratory colony at the Coordenação de Pesquisas em Ciências da Saúde (CPCS/INPA) in tap water. Stock solutions or suspensions of extracts in DMSO or deionized water $(50 \mathrm{mg} / \mathrm{mL})$ were prepared. Each stock solution $(100 \mu \mathrm{L})$ was then transferred to plastic cups containing 10 third instar (three-day old) larvae in tap water having a final volume of $10 \mathrm{~mL}$ and a final extract concentration of $500 \mu \mathrm{g} / \mathrm{mL}$. Negative controls were prepared analogously, substituting $100 \mu \mathrm{L}$ of tap water or DMSO for sample solution in each cup, resulting in a final DMSO concentration of $1 \%$. Each experiment was run in triplicate and compared with a control set after $24 \mathrm{~h}$ at $26-27^{\circ} \mathrm{C}$. Dead larvae were counted and the larvicidal activity expressed as \% mortality based on live larvae present initially. In general, no dead larvae were observed in the controls after $24 \mathrm{~h}$.

\section{RESULTS AND DISCUSSION}

Table 1 presents ethnobotanical and other information on the species investigated in this study. A number of these plants are traditionally used medicinal plants for the treatment of malaria, fevers, liver problems, and other symptoms caused by malaria infections, whose study is a major focus of our research group. Other plants studied were collected using a random sampling technique in INPA forest reserves in or near Manaus (Reserva Florestal Adolpho Ducke, Reserva da Campina / ZF-2). Still other species, from such genera as Aspidosperma (Apocynaceae) and Piper (Piperaceae), or from families such as Simaroubaceae, were studied here as part of a systematic approach to the investigation of the chemistry and biological activity of Amazon flora of these, and other taxonomic groups. Thus, the plants studied herein were not selected a priori for their known insecticidal, larvicidal or repellent properties. The discovery of larvicidal activity, as described below, serves as a demonstration of the power of bioprospection in the discovery of new larivicidal extracts and compounds based on many plants for which no such activity has been described or is known in the literature.

Tables 2 and 3 present, respectively, data for larvicidal and inactive plant extracts. Comparison of the results presented in Tables 2 and 3 reveals in a general way that extracts prepared from the less polar solvents ethanol and methanol were more active against $A$. aegypti larvae than 


\section{\begin{tabular}{l|l} 
ACTA & SCREEnING Of PLANTS FOUND IN THE StATE OF AMAZONAS, BRAZIL
\end{tabular} \\ AMAZONICA $\quad$ FOR LARVICIDAL ACTIVITY AGAINST Aedes aegypti LARVAE}

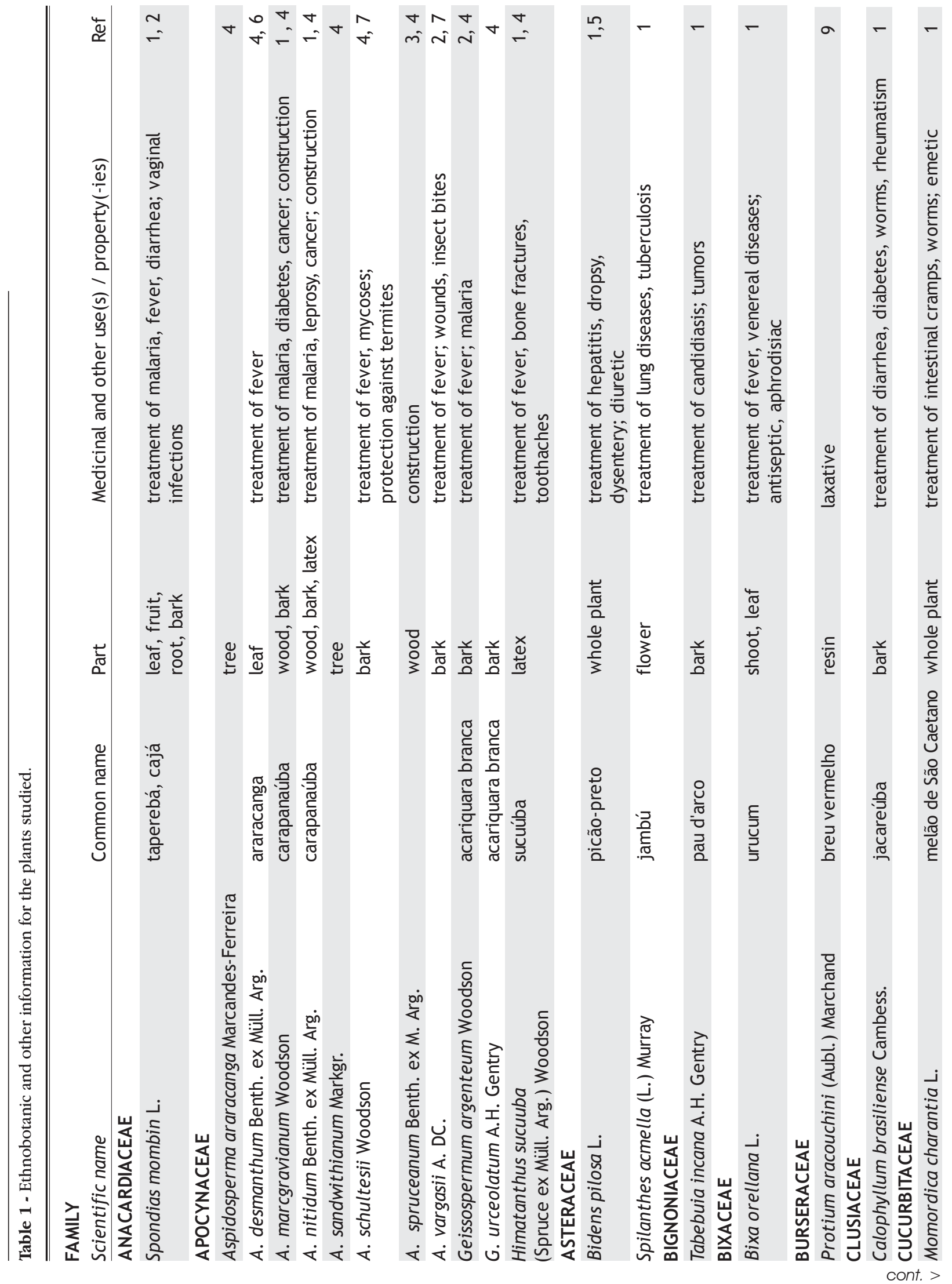




\section{ACTA \\ AMAZONICA \\ SCREENING OF PLANTS FOUND IN THE STATE OF AMAZONAS, BRAZIL \\ FOR LARVICIDAL ACTIVITY AGAINST Aedes aegypti LARVAE}

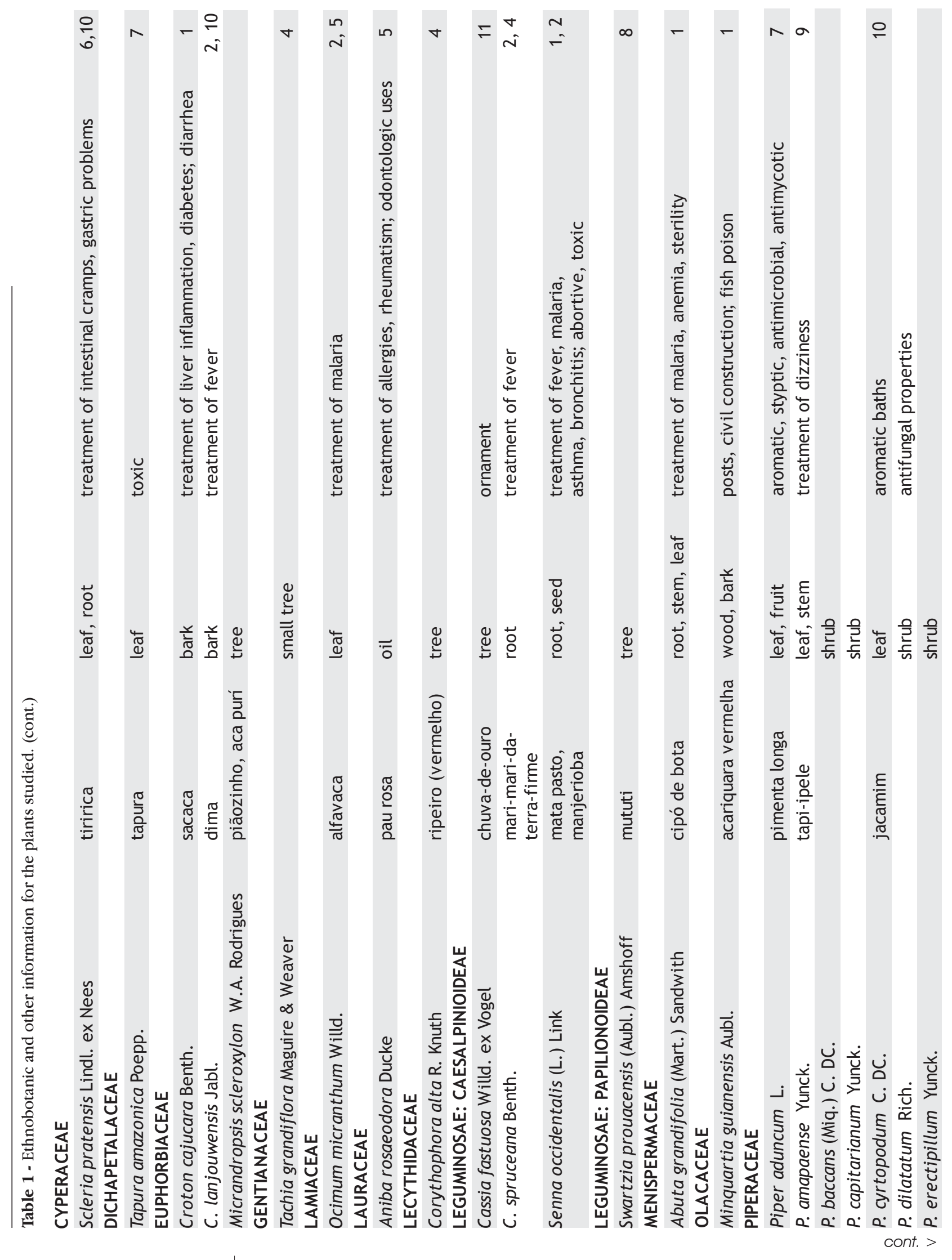




\section{\begin{tabular}{l|l}
\hline ACTA & SCREENING OF PLANTS FOUND IN THE STATE OF AMAZONAS, BRAZIL
\end{tabular} \\ AMAZONICA FOR LARVICIDAL ACTVITY AGAINST Aedes aegypti LARVAE}

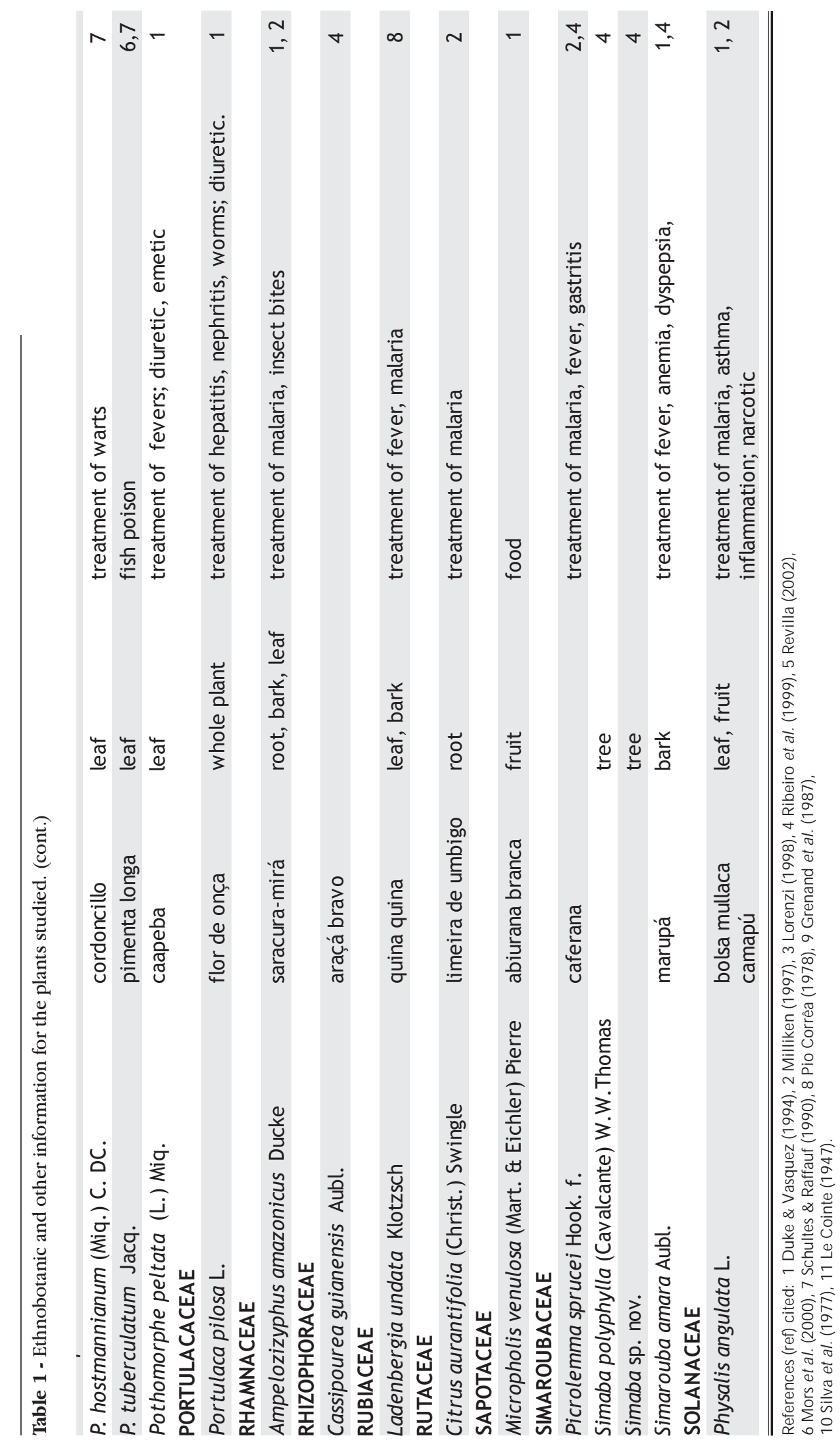




\section{ACTA \\ AMAZONICA}

Table 2 - Data for Plant Extracts Exhibiting Lethality to Aedes aegypti Larvae.

\begin{tabular}{|c|c|c|c|}
\hline FAMILY & Part $^{1}$ & Extract $^{2}$ & Mortality \\
\hline Scientific name & & & $(\%)$ \\
\hline \multicolumn{4}{|l|}{ APOCYNACEAE } \\
\hline Aspidosperma araracanga Marcandes-Ferreira & Bk & M & 4 \\
\hline A. marcgravianum Woodson & Bk & W & 4 \\
\hline A. schultesii Woodson & Bk & M & 33 \\
\hline \multicolumn{4}{|l|}{ ASTERACEAE } \\
\hline Bidens pilosa L. & Rt & M & 10 \\
\hline Spilanthes acmella (L.) Murray & Wp & M & 37 \\
\hline \multicolumn{4}{|l|}{ BIGNOGNACEAE } \\
\hline Tabebuia incana A. H. Gentry & $\mathrm{Bk}$ & $\mathrm{E}$ & 4 \\
\hline \multicolumn{4}{|l|}{ CLUSIACEAE } \\
\hline Calophyllum brasiliense Cambess. & Bk & W & 20 \\
\hline \multicolumn{4}{|l|}{ CUCURBITACEAE } \\
\hline Mormodica charantia L. & St & M & 7 \\
\hline \multicolumn{4}{|l|}{ DICHAPETALACEAE } \\
\hline \multirow[t]{2}{*}{ Tapura amazonica Poepp. } & $\mathrm{Br}$ & M & 7 \\
\hline & Rt & M & 100 \\
\hline \multicolumn{4}{|l|}{ EUPHORBIACEAE } \\
\hline \multirow[t]{2}{*}{ Croton cajucara Benth. } & Lf & M & 4 \\
\hline & $\mathrm{Br}$ & M & 83 \\
\hline \multirow[t]{2}{*}{ C. lanjouwensis Jabl. } & $\mathrm{Fr}, \mathrm{Bk}$ & M & 90 \\
\hline & Sd & M & 30 \\
\hline Micrandropsis scleroxylon W.A. Rodrigues & Rt & M & 7 \\
\hline \multicolumn{4}{|l|}{ GENTIANACEAE } \\
\hline \multirow[t]{4}{*}{ Tachia grandiflora Maguire \& Weaver } & St & M & 7 \\
\hline & Lf & M & 10 \\
\hline & $\mathrm{Br}$ & M & 30 \\
\hline & Rt & $\mathrm{E}$ & 64 \\
\hline
\end{tabular}

\section{LAURACEAE}

Aniba rosaeodora Ducke

$\begin{array}{ccc}\text { Lf } & \text { M } & 43 \\ \mathrm{Br} & \mathrm{W} & 33 \\ \text { Wd } & M & 23\end{array}$

\section{PIPERACEAE}

Piper aduncum L.

P. amapense Yunck.

Lf $\quad$ M 100

Rt

Lf

P. capitarianum Yunck.

P. dilatatum Rich.

$\mathrm{Br}, \mathrm{St}$

Lf

P. hostmanianum (Miq.) C. DC.

$\mathrm{Br}, \mathrm{St}$

Lf

$\mathrm{Br}, \mathrm{St}$

P. tuberculatum Jacq.

Lf

$\mathrm{Fr}$

$\mathrm{Fr}$

$\mathrm{Br}, \mathrm{St}$

Pothomorphe peltata (L.) Miq.

Lf

Rt

$\begin{array}{ll}M & 100 \\ M & 100\end{array}$

$M \quad 17$

W 4

M 4

$\begin{array}{ll}M & 7\end{array}$

$\begin{array}{ll}M & 17\end{array}$

M 7

M $\quad 100$

$M \quad 100$

W 53

M $\quad 100$

E 7

E 7




\section{ACTA \\ AMAZONICA}

Table 2 - Data for Plant Extracts Exhibiting Lethality to Aedes aegypti Larvae. (cont.)

\section{SIMAROUBACEAE}

Picrolemma sprucei Hook.

\begin{tabular}{lll} 
St & M & 57 \\
$\mathrm{Rt}$ & $\mathrm{M}$ & 74 \\
& $\mathrm{~W}$ & 44 \\
$\mathrm{Br}$ & $\mathrm{M}$ & 100 \\
$\mathrm{Br}$ & $\mathrm{M}$ & 70 \\
$\mathrm{Br}$ & $\mathrm{M}$ & 37 \\
\hline
\end{tabular}

Simaba polyphylla (Cavalcante) W.W. Thomas

Simaba sp. nov.

Simarouba amara Aubl.

1 - Bk - bark; Br - branch; Fl - flower; Fr - fruit; Lf - leaf; Rt - root; Sd - seed; St - stem; W d - wood; Wp - whole plant.

2 - E - ethanol; M - methanol; W - water.

Table 3 - Inactive Plant Extracts.

\begin{tabular}{|c|c|}
\hline Nome Científico & $\operatorname{Part}(\mathrm{s})^{1}[\text { Extract(s) }]^{2}$ \\
\hline Abuta grandiflora (Mart.) Sandwith & $\mathrm{V}[\mathrm{M}, \mathrm{W}]$ \\
\hline Ampelozizyphus amazonicus Ducke & $\mathrm{V}[\mathrm{M}, \mathrm{W}]$ \\
\hline Aniba rosaeodora Ducke & $\operatorname{Br}[M], \mathrm{Lf}[\mathrm{W}], \mathrm{Wd}[\mathrm{W}]$ \\
\hline Aspidosperma araracanga Marcandes-Ferreira & $\mathrm{Bk}[\mathrm{W}]$ \\
\hline A. desmanthum Benth. ex Müll. Arg. & $\mathrm{Bk}[\mathrm{M}, \mathrm{W}]$ \\
\hline A. marcgravianum Woodson & Bk $[M]$ \\
\hline A. nitidum Benth. ex Müll. Arg. & $\mathrm{Bk}[\mathrm{M}, \mathrm{W}]$ \\
\hline A. sandwithianum Markgr. & $\mathrm{Bk}[\mathrm{M}, \mathrm{W}]$ \\
\hline A. schultesii Woodson & Bk [W] \\
\hline A. spruceanum Benth. ex M. Arg. & $\mathrm{Bk}[\mathrm{M}]$ \\
\hline A. vargasii A. DC. & $\mathrm{Bk}[\mathrm{M}]$ \\
\hline Bidens pilosa L. & Rt [W] \\
\hline Bixa orellana L. & Lf $[M, W]$ \\
\hline Calophyllum brasiliense Cambess. & $\mathrm{Bk}[\mathrm{W}]$ \\
\hline Cassia fastuosa Willd. ex Vogel & Lf [M], Rt [W] \\
\hline C. spruceana Benth. & Rt $[E]$ \\
\hline Cassipourea guianensis Aubl. & Rt $[M]$ \\
\hline Citrus aurantifolia (Christ.) Swingle & RT [W] \\
\hline Corythophora alta R. Knuth & Rt $[M]$ \\
\hline Croton cajucara Benth. & $\mathrm{Br}[\mathrm{W}], \mathrm{Lf}[\mathrm{M}, \mathrm{W}]$ \\
\hline C. lanjouwensis Jabl. & $\operatorname{Br}[M, W], \operatorname{Fr}[W], \operatorname{Lf}[M, W], S d[W]$ \\
\hline Geissospermum argenteum Woodson & Bk $[E, M]$ \\
\hline G. urceolatum A.H. Gentry & $\mathrm{Bk}[\mathrm{E}, \mathrm{M}]$ \\
\hline Himatanthus sucuuba (Spruce ex Müll. Arg.) Woodson & $\mathrm{Bk}[\mathrm{M}, \mathrm{W}]$ \\
\hline Ladenbergia undata Klotzsch & $\mathrm{Bk}[\mathrm{M}, \mathrm{W}]$ \\
\hline Micropholis venulosa (Mart. \& Eichler) Pierre & Rt $[M]$ \\
\hline Minquartia guianensis Aubl. & $\mathrm{Bk}[\mathrm{M}]$ \\
\hline Momordica charantia L. & St/Lf [W] \\
\hline Ocimum micranthum Willd. & Fl/Lf $[M]$ \\
\hline Physalis angulata L. & Rt $[M, W]$, St $[M, W]$, St/Lf $[M, W]$ \\
\hline Picrolemma sprucei Hook & Lf $[M, W]$, St $[W]$ \\
\hline Piper aduncum L. & $\operatorname{Br}[M, W]$, Lf $[W]$, Rt $[W]$, St $[M, W]$ \\
\hline P. amapaense Yunck. & $\operatorname{Br}[M], \operatorname{Lf}[M, W], \operatorname{Rt}[M]$ \\
\hline P. baccans (Miq.) C. DC. & $\operatorname{Br}[M, W]$, Lf $[M, W]$, Rt [W] \\
\hline
\end{tabular}




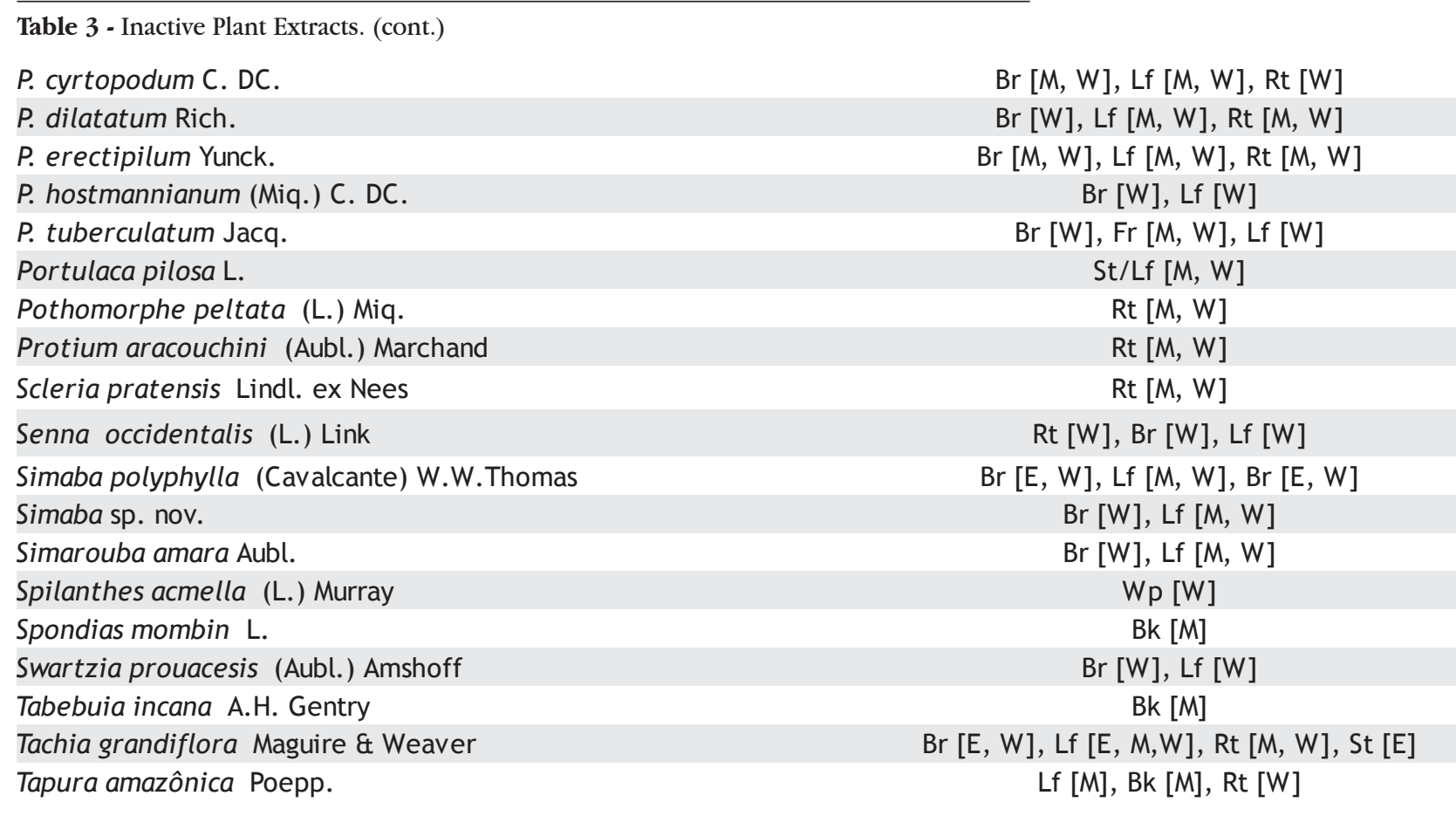

1 - Bk - bark; Br - branch; Fl - flower; Fr - fruit; Lf - leaf; Rt - root; Sd - seed; St - stem; W d - wood; W p - whole plant.

2 - E - ethanol; M - methanol; W - water.

the extracts prepared by extraction with the more polar water as solvent, which is probably an indication that toxicity to these larvae should be associated in general with substances of medium or even low polarity.

Our results confirmed the toxicity of several plant species which have been described as being toxic or are used traditionally for their toxicity. For example, methanol root extract of Tapura amazonica Poepp. was highly lethal to $A$. aegypti larvae which is interesting in light of the fact that it has been described by Colombian native indians as being a toxic species (Table 1; Schultes \& Raffauf, 1990). In similar fashion, P. tuberculatum Jacq. presented highly lethal extracts in the assay and is, according to traditional use, an effective fish poison (Table 1). Lastly, Picrolemma sprucei Hook (caferana), which exhibited larvicidal root and stem extracts in the present study, is known for its toxic effects towards the human fetus, being used widely in the State of Amazonas and Manaus as an abortifacient tea (Pohlit et al., unpublished data).

Another Piper species, $P$. aduncum L., exhibited good activity against Aedes aegypti (Table 2) and is known to produce the larvicidal phytochemical compound, dillapiole, which has been shown by Bernard et al. (1995) to be active against another Aedes sp.. Given that $P$. aduncum is a fast-growing, invasive species, it is potentially useful as an industrial source of dillapiole and other active phytochemicals.
Another interesting observation is that larvicidal activity is definitely specific to certain parts of plants, such as $P$. aduncum, which exhibited very active methanol leaf and root extracts (Table 2), however, extracts of other parts of this plant were inactive (Table 3 ). Other examples of this specificity of insecticidal activity to certain plant parts is evidenced by comparing the data presented in Tables 2 and 3.

Finally, it is important to note that even the low mortality exhibited by some extracts during screening can be significant for the discovery of bioactive phytochemicals. An example of this is the weak activity of the ethanol root and leaf extracts of Pothomorphe peltata (L.) Miq. (each exhibiting only $7 \%$ mortality at $500 \mu \mathrm{g} / \mathrm{mL}$, Table 2 ). In further work, bioassay-guided fractionation of this ethanol root extract in our labs yielded very active intermediate fractions and isolation of the phytochemical larvicide, 4nerolidylcatechol, which exhibited very significant lethality towards Aedes aegypti larvae and was shown by chromatographic analytical methods to be a major component of both root and leaf extracts (Pinto, 2002).

\section{CONCLUSION}

A number of larvicidal plants were identified during this work. Several of these are now under biomonitored phytochemical analysis and should yield further examples of isolated larvicidal phytochemicals in the future. 


\section{ACTA \\ AMAZONICA}

SCREENING OF PLANTS FOUND IN THE STATE OF AMAZONAS, BRAZIL

FOR LARVICIDAL ACTIVITY AGAINST Aedes aegypti LARVAE

\section{ACKNOWLEDGEMENTS}

The authors proudly recognize the financial support provided by the Brazilian National Council for Scientific and Technological Development (CNPq; Grant nos. 520.354/99-0 and 550.260/013). The following people are thankful to these institutions for scholarships: ELJQ (DTI-MCT), SMN (DCR-CNPq), ACSP and EVMS (Mestr-CAPES), SKRM (AP-CNPq), MCH (IC-CNPq), KSS (AT-CNPq), AMA, ACSP, LCD, EOG, PSP and SGS (PIBIC-INPA-CNPq).

\section{LITERATURE CITED}

Bandara, K.A.N.P. et al. 2000. Insecticidal piperidine alkaloid from Microcos paniculata stem bark. Phytochemistry, 54(1):29-32.

Bergeron, C. et al. 1996. Screening of plants used by North American indians for antifungal, bactericidal, larvicidal, and molluscicidal activities. Intl. J. Pharmacog., 34(4):233-242.

Bernard, C.B. et al. 1995. Insecticidal defenses of Piperaceae from the neotropics. J. Chem. Ecol., 21(6):801-814.

Chantraine, J.M. et al. 1998. Insecticidal activity of essential oils on Aedes aegypti larvae. Phytother. Res., 12(5):350-354.

Chariandy, C.M. et al. 1999. Screening of medicinal plants from Trinidad and Tobago for antimicrobial and insecticidal properties. J. Ethnopharmacol., 64(3):265-270.

Ciccia, G., Coussio, J., Mongelli, E. 2000. Insecticidal activity against Aedes aegypti larvae of some medicinal South American plants. J. Ethnopharmacol., 72(1-2): 185-189.

Diallo, D. et al. 2001. Screening of Malian medicinal plants for antifungal, larvicidal, molluscicidal, antioxidant and radical scavenging activities. Phytother. Res., 15(5):401-406.

Duke, J.A.; Vasquez, R. 1994. Amazonian Ethnobotanical Dictionary. CRC Press, Florida, United States. 215 pp.

Grenand, P. Moretti, C., Jacquemin, H. 1987. Pharmacopées traditionnelles en Guyane: Créoles, Palikur, Wayãpi. Éditions de l'ORSTOM, Paris. 569pp.

Hostettmann, K., Potterat, O. 1997. Strategy for the isolation and analysis of antifungal, molluscicidal and larvicidal agents from tropical plants. In: Phytochemicals for Pest Control. ACS Sym. Ser.. v. 658. American Chemical Society, Washington. p. 14-26.

Latha, C., Ammini, J. 2000. Curcuma raktakanda is a potential larvicide for mosquito control. Pharm. Biol., 38(3):167-170.

Le Cointe, P. 1947. Árvores e Plantas Úteis: indígenas e aclimadas. $2^{\mathrm{a}}$ ed.. Companhia Editora Nacional, São Paulo, 506 pp.

Lee, S.E. 2000. Mosquito larvicidal activity of pipernonaline, a piperidine alkaloid derived from long pepper, Piper longum. J. Amer. Mosq. Ctrl. Assoc., 16(3):245-247.

Lorenzi, H. 1998. Árvores Brasileiras: Manual de Identificação e Cultivo de Plantas Arbóreas Nativas do Brasil. Editora Plantarum, Nova Odessa (SP), Brazil. 352 pp.

Macedo, M. E. et al. 1997. Screening of Asteraceae (Compositae) plant extracts for larvicidal activity against Aedes fluviatilis (Diptera: Culicidae). Mem. Inst. Osw. Cruz, 92(4):565-570.

Marston, A. et al. 1993. Search for antifungal, molluscicidal and larvicidal compounds from African medicinal plants. $J$. Ethnopharmacol., 38(2-3):215-233.
Milliken, W. 1977.Plants for Malaria. Plantas for Fever: Medicinal Species in Latin

AMERICA - a bibliographic survey. Whitstable Litho, United Kingdom. 116pp.

Mors, W. B., Rizzini, C. T., Pereira, N. A. 2000. Medicinal Plants of Brazil. DeFilipps, R.A. Ed.. Reference Publication, Algonac (U.S.A.). 501 p.

Oberlies, N.H. et al. 1998. Cytotoxic and Insecticidal Constituents of the Unripe Fruit of Persea americana. $J$. Nat. Prod., 61(6): 781-785.

Park et al. 2002. Larvicidal activity of isobutylamides identified in Piper nigrum fruits against three mosquito species. J. Agric. Food Chem., 50(7):1866-1870.

Pinto, A.C.S., 2002. Estudo fitoquímico e biológico de Pothomorphe peltata (L.) Miquel (Piperaceae), Master's Dissertation-Natural Products Chemistry, UFAM, Manaus.

Pio Corrêa, M. 1978. Dicionário das Plantas Úteis do Brasil e das Exóticas Cultivadas, v. 1-6, Ministério da Agricultura-Instituto Brasileiro de Desenvolvimento Florestal, Rio de Janeiro.

Pushpalatha E., Muthukrishnan, J. 1999. Efficacy of two tropical plant extracts for the control of mosquitoes. J. Appl. Entom., 123(6): 369-373.

Quignard, E.L.J. et al. 2003. Screening of plants found in Amazonas state for lethality towards brine shrimp. Acta Amazonica, 33(1):93-104.

Rahuman, A. A. et al. 2000. Effect of Feronia limonia on mosquito larvae. Fitoterapia, 71:553-557.

Revilla, J. 2002. Apontamentos para a Cosmética Amazônica. SEBRAE-AM / INPA, Manaus. 532pp.

Ribeiro, J.E.L. da S. et al. 1999. Flora da Reserva Ducke - Guia de identificação das plantas vasculares de uma floresta de terra firme na Amazônia Central. INPA / DFID, Manaus. 800pp.

Sathiyamoorthy, P. et al. 1997. Larvicidal activity in desert plants of the Negev and Bedouin market plant products. Intl. J. Pharmacog., 35(4):265-273.

Schultes, R.E., RAFFAUF, R.F. 1990. The Healing Forest: Medicinal and Toxic Plants of the Northwest Amazonia. Dioscorides Press, Oregon, United States. 484pp.

Sharma, N. et al. 1998. Larvicidal activity of Gliricidia sepium against mosquito larvae of Anopheles stephansi, Aedes aegypti and Culex quinquefasciatus. Pharm. Biol., 36(1):3-7.

Silva, M.F., Lisbôa, P.L.B., Lisbôa, R.C.L. 1977. Nomes vulgares de Plantas Amazônicas. INPA, Manaus. 222pp.

Sukamar, K., Perich, M.J., Boobar, L.R. 1991. Botanical derivatives in mosquito control: a review.J. Am. Mosq. Contr. Ass., 7:210-237.

Thorsell, W.A. et al. 1998. Efficacy of plant extracts and oils as mosquito repellents. Phytomedicine, 5(4):311-323.

RECEBIDO EM 30/12/2002
ACEITO EM 07/01/2004 
